\title{
Pastoralny wymiar nauczania papieża Franciszka do dyplomatów
}

\section{PASTORAL DIMENSION OF POPE FRANCIS' TEACHING ADDRESSED TO DIPLOMATS}

Diplomacy in the contemporary world is put into jeopardy and faces numerous threats such as armed conflicts, terrorism or economic crises. It is often the case the above problems stem from failure to implement moral values in the international life and relations. The situation requires an in-depth reflection and change of mentality. The issue can be handled best with the teaching of Pope Francis addressed to diplomats. He presents his thoughts on the world and the changes which take place therein together with the assessment of the present events, all this being made via a thorough analysis of the development of international relations and specific incidents around the world. By addressing international issues the Pope shows paths which modern diplomacy should follow. The problems of utmost importance are respecting human dignity, overcoming poverty, striving for brotherhood and dialog as well as commitment to achieve world peace. The above topics gain a pastoral dimension in the teaching of Pope Francis addressed to diplomats.

Key words: diplomacy, moral value, Francis, moral diplomacy. 


\section{Wprowadzenie}

Dyplomacja we współczesnym świecie zmaga się z wieloma zagrożeniami takimi, jak: konflikty zbrojne, terroryzm czy kryzysy ekonomiczne. Często przyczyny tych problemów leżą u podstaw braku urzeczywistniania wartości moralnych w życiu międzynarodowym. Sytuacja ta domaga się pogłębionej refleksji i przemiany mentalności. Z pomocą w tej kwestii przychodzi nauczanie papieża Franciszka skierowane do dyplomatów. Papież jest nie tylko głową Kościoła katolickiego, ale także - w świetle prawa międzynarodowego - głową państwa: Stolicy Apostolskiej. Przemawiając do dyplomatów, dokonuje oceny najważniejszych wydarzeń z życia międzynarodowego i zwraca uwagę na te problemy, które wymagają niezwłocznej reakcji ze strony dyplomacji. Styl nauczania Franciszka różni się od jego poprzedników, gdyż z jednej strony jest pozbawiony skomplikowanej terminologii teologicznej stając się bardziej zrozumiały, zaś z drugiej strony wpływa na łatwość nawiązywania bezpośrednich relacji, łamiąc utarte schematy postępowania. Nuncjusz apostolski w Polsce abp Celestino Migliore zwrócił uwagę, że bezpośredniość i naturalność, które charakteryzują styl nauczania Papieża powinny być cechami każdego współczesnego lidera ${ }^{1}$.

Celem niniejszej publikacji jest ukazanie pastoralnego wymiaru nauczania Franciszka skierowanego do dyplomatów. Papież dzieli się z nimi refleksją na temat świata, zachodzących w nim zmian czy oceną aktualnych wydarzeń. Dokonuje tego za pomocą starannej analizy rozwoju stosunków międzynarodowych i poszczególnych wydarzeń na całym świecie. Papieskie nauczanie w tym zakresie jest $\mathrm{z}$ jednej strony komentarzem do aktualnych wydarzeń na arenie międzynarodowej, zaś z drugiej strony ukazuje kierunki, którymi powinna podążać dyplomacja. Już samo ich przytoczenie wskazuje, że są najpilniejszymi sprawami, z którymi współczesna dyplomacja powinna się zmierzyć.

\section{Respektowanie godności człowieka}

Poszanowanie godności człowieka jest pierwszym wskazaniem pastoralnym dla dyplomatów. W trakcie wizyty w Parlamencie Europejskim i w Radzie Europy w Strasburgu 25 listopada 2014 roku Franciszek zwrócił uwagę, że godność człowieka była kluczem do odbudowy świata po drugiej wojnie światowej. W powojennej rzeczywistości promowanie godności człowieka, oznaczało także uznanie

Por. Franciszek - papież niewygodny? http://www.niedziela.pl/artykul/6887/ Franciszek---papiez-niewygodny (23.11.2013). 
jego podstawowych praw, których nie mógł być pozbawiony. Jednak we współczesnym świecie kryzys finansowy i gospodarczy spowodował, że ,istota ludzka jest uważana za dobro konsumpcyjne, które można użyć, a potem wyrzucić"2. $\mathrm{Z}$ tego powodu godność człowieka i przysługujące mu prawa ulegają różnorodnym zagrożeniom, które uniemożliwiają ich należyte respektowanie.

Pojawianiu się tych zagrożeń sprzyja odrzucenie etyki, którą uważa się za rzecz szkodliwą, zbyt ludzką, relatywizującą pieniądz i władzę, odrzucającą manipulację innymi. Franciszek podkreśla, że dzieje się tak dlatego, iż etyka prowadzi do Boga, który nie podlega kategoriom rynkowym. Zatem politycy, dyplomaci czy ekonomiści odrzucając etykę, odrzucają samego Boga, który nie jest zarządzany i stanowi zagrożenie dla wielu partykularnych interesów, gdyż wzywa człowieka do pełnego rozwoju i urzeczywistniania siebie w codziennym życiu ${ }^{3}$. W ocenie Papieża coraz bardziej widoczny globalny konflikt wartości powinien skłonić całą wspólnotę międzynarodową do wypracowania powszechnie podzielanych wartości, które na nowo umożliwią globalną współpracę dla wspólnego dobra, jakim jest godności osoby ludzkiej ${ }^{4}$. W tym kontekście pomocne jest przeprowadzenie takiej reformy finansowej, która w oparciu o zasady etyczne, zrodziłaby dla wszystkich zdrową reformę gospodarki. Wymaga to jednak odważnej zmiany postawy wielu przywódców politycznych. Jest to wyzwanie, które domaga się bezinteresownej solidarności i powrotu do etyki opowiadającej się po stronie człowieka. Dobro wspólne nie powinno być zwykłym dodatkiem czy małowartościowym schematem pojęciowym, włączonym do programów politycznych, lecz ich integralną częścią. Wytworzy się wówczas nowa mentalność polityczna i ekonomiczna, która przyczyni się do przeobrażenia dychotomii między sferą ekonomiczną i sferą społeczną w zdrowe współżycie ${ }^{5}$. „W świecie dążącym do globalizacji ekonomicznej i kulturowej trzeba podejmować wszelkie wysiłki, aby wzrost i rozwój były dostępne dla wszystkich, a nie tylko dla pewnej

$2 \quad$ Franciszek, Między godnościa i transcendencja, przemówienie w Parlamencie Europejskim (25 listopada 2014 r.), „L'Osservatore Romano” wydanie polskie (dalej: L'OssRom (PL) 12 (2014), s. 9. dorów przy Stolicy Apostolskiej (16 maja 2013 r.), L’OssRom (PL) 7 (2013), s. 13.

4 Por. idem, Nie można akceptować prześladowań z powodu wiary, przemówienie do uczestników kongresu poświęconego wolności religijnej i prawu międzynarodowemu (20 czerwca 2014 r.), L'OssRom (PL) 7 (2014), s. 14.

Por. idem, Pieniadz musi..., op. cit., s. 14. 
Teologia papieża Franciszka

części ludzkości”" Jeżeli rozwój ten nie będzie zrównoważony, sprawiedliwy i uwzględniał praw ubogich - nie będzie autentyczny?

Papież podkreśla, że negowanie godności człowieka powoduje, iż zagrożeniu ulega pokój ${ }^{8}$. Dlatego pielgrzymując do Izraela i spotykając się z prezydentem tego państwa Franciszek zwrócił uwagę, że budowa pokoju na świecie wymaga poszanowania wolności i godności wszystkich bez wyjątku.

Należy stanowczo odrzucić wszystko, co jest sprzeczne z dążeniem do pokoju i naznaczonego szacunkiem współistnienia żydów, chrześcijan i muzułmanów. Uciekanie się do przemocy i terroryzmu, wszelkiego rodzaju dyskryminację ze względów rasowych lub religijnych, roszczenie prawa do narzucania swojego punktu widzenia kosztem praw innych osób, antysemityzm we wszystkich możliwych formach, a także przemoc czy przejawy nietolerancji wobec osób lub miejsc kultu żydów, chrześcijan i muzułmanów9 .

Zdaniem Papieża to wszystko stanowi o pogwałceniu prawa do wolności oraz godności każdego człowieka ${ }^{10}$.

\section{Przezwyciężanie ubóstwa}

Kolejnym wezwaniem pastoralnym dla dyplomatów jest przezwyciężanie ubóstwa. Na temat materialnego i duchowego ubóstwa Franciszek mówił już w trakcie pierwszego spotkania z korpusem dyplomatycznym 22 marca 2013 roku. Szczególną uwagę poświęcił ubóstwu duchowemu, które dotyka w coraz większym stopniu kraje bogate, a nie biedne. Benedykt XVI określił to zjawisko jako dyktaturę relatywizmu, która czyni człowieka miarą samego siebie i zagraża współżyciu międzyludzkiemu. Uniemożliwia to dążenie do

Idem, Pokojowe wspótistnienie różnych religii jest możliwe, spotkanie z przedstawicielami rządu i władz państwowych w pałacu prezydenckim w Tiranie (21 września 2014 r.), L’OssRom (PL) 10 (2014), s. 11.

Por. ibidem.

Por. Franciszek, Główną droga pokoju jest dialog, audiencja dla korpusu dyplomatycznego (12 stycznia 2014 r.), L'OssRom (PL) 2 (2014), s. 17.

Ibidem.

Por. Franciszek, Budowanie pokoju wymaga poszanowania wolności i godności wszystkich, przemówienie podczas wizyty u prezydenta Izraela (26 maja 2014 r.), L'OssRom (PL) 6 (2014), s. 23-24. 
prawdziwego i trwałego pokój na świecie, gdyż człowiek domagając się tylko własnego dobra, nie troszczy się o dobro innych ${ }^{11}$.

Pomimo iż coraz bardziej widoczne jest zmniejszanie się absolutnego ubóstwa, to nie można nie dostrzec poważnego wzrostu ubóstwa względnego. Chodzi tu o nierówności między ludźmi i grupami mieszkającymi razem $\mathrm{w}$ danym regionie lub w konkretnym kontekście historyczno-kulturowym, które często wynikają z podłoża ekonomicznego. We współczesnym świecie poważne kryzysy finansowe i gospodarcze, których źródłem z jednej strony jest pogoń za dobrami materialnymi i oddalaniem się od Boga i drugiego człowieka, zaś z drugiej strony, zubożenie relacji międzyludzkich i społecznych, powodują poszukiwanie zadowolenia, szczęścia oraz bezpieczeństwa w konsumpcji i zysku, które wykraczają poza logikę zdrowej gospodarki ${ }^{12}$.

Ubóstwo względne powodują także konflikty w różnych częściach świata. Przykładem jest rejon Półwyspu Somalijskiego i Wielkich Jezior, gdzie wiele tysięcy ludzi zostało zmuszonych do ucieczki i opuszczenia własnej ojczyzny z powodu niedostatku żywności oraz stosowanej wobec nich przemocy ${ }^{13}$. Wielu z tych ludzi żyje jak przesiedleńcy w obozach dla uchodźców. Poszukują oni często lepszego życia i wyruszają w podróż, która kończy się tragicznie. Papież ma tu na myśli licznych migrantów z Ameryki Łacińskiej, którzy kierują się do Stanów Zjednoczonych oraz uchodźców z Afryki oraz Bliskiego Wschodu szukających azylu w Europie. Potwierdzeniem skali tych dramatów jest wyspa Lampedusa, gdzie tysiące uchodźców zginęło i w dalszym ciągu ginie na Morzu Śródziemnym w poszukiwaniu lepszego życia w Europie ${ }^{14}$.

W ocenie Franciszka przezwyciężanie ubóstwa w wymiarze duchowym, absolutnym czy względnym domaga się podjęcia zdecydowanych działań dyplomatycznych. Powinny być one oparte na solidarnym współdziałaniu całej wspólnoty międzynarodowej. Jest to trudna droga, która wymaga wiele wysiłku na rzecz powrotu cnót takich, jak: roztropność, umiarkowanie, sprawiedliwość i męstwo. Cnoty te są

11 Por. idem, Działajcie na rzecz budowana pokoju, audiencja dla korpusu dyplomatycznego akredytowanego przy Stolicy Apostolskiej (22 marca 2013 r.), L'OssRom (PL) 5 (2013), s. 26.

12 Por. idem, Braterstwo podstawa pokoju i droga do niego, Orędzie na Światowy Dzień Pokoju (1 stycznia 2014 r.), L’OssRom (PL) 1 (2014), s. 7.

13 Por. Franciszek, Główna drogą..., op. cit., s. 18.

14 Por. ibidem. 
niezbędne do budowy i utrzymania społeczeństwa na miarę ludzkiej godności ${ }^{15}$.

\section{Braterstwo podstawą pokoju}

Kolejnym wskazaniem pastoralnym dla dyplomatów jest dążenie do braterstwa. W trakcie spotkania z korpusem dyplomatycznym 13 stycznia 2014 roku Franciszek stwierdził, że braterstwo jest podstawą pokoju i drogą prowadzącą do niego ${ }^{16}$. Papieskie rozważania w tym zakresie są kontynuacją przesłania na Światowy Dzień Pokoju z dnia 1 stycznia 2014 roku, w którym mówił o braterstwie jako fundamencie pokoju. Dla Franciszka braterstwo jest istotnym wymiarem człowieka jako istoty społecznej. Powinno to prowadzić do postrzegania i traktowania każdej osoby jako prawdziwej siostry i prawdziwego brata. Bez tego budowanie stabilnego i trwałego pokoju staje się niemożliwe. Papież podkreśla, że najpierw człowiek uczy się braterstwa w rodzinie. „Rodzina jest źródłem wszelkiego braterstwa, a zatem również podstawą pokoju i główną drogą do niego, ponieważ z racji swego powołania powinna «zarażać» świat swą miłością ${ }^{17 "}$.

Zdaniem Franciszka zrozumienie prawdziwego braterstwa między ludźmi zakłada i wymaga ujęcia jego transcendentnego wymiaru. Fundamentalne znaczenie w tym poznaniu odgrywa Pismo Święte. Papież w pierwszej kolejności zwraca uwagę na fragment ze Starego Testamentu: „Gdzie jest brat twój, Abel?” (Rdz 4,9). W jego ocenie z historii pierwszej rodziny odczytujemy genezę społeczeństwa oraz ewolucję relacji między ludźmi i narodami. Dotyczy to szczególnie historii Kaina i Abla, która ukazuje, że w ludzkość wpisane zostało powołanie do braterstwa, ale również możliwość zdrady tego powołania. We współczesnym świecie w zdradą tą jest m.in. codzienny egoizm, który stanowi podłoże wielu konfliktów, wojen i niesprawiedliwości. W ich konsekwencji wielu ludzi umiera z rąk braci i sióstr, którzy nie potrafią uznać swego braterstwa oraz tego, że są istotami stworzonymi do wzajemności i współdziałania ${ }^{18}$.

Kolejny fragment, który przytacza Papież pochodzi z Nowego Testamentu: „A wy wszyscy jesteście braćmi” (Mt 23,8). Franciszek dokonując parafrazy słów Jezusa ujął je w następujący sposób: „skoro jeden

\footnotetext{
15 Por. Franciszek, Braterstwo podstawa..., op. cit., s. 8.

16 Por. idem, Gtówna drogą..., op. cit., s. 16.

17 Idem, Braterstwo podstawa..., op. cit., s. 4.

18 Por. ibidem, s. 5.
} 
jest wasz Ojciec, który jest Bogiem, to wy wszyscy jesteście braćmi”"19. Braterstwo pochodzi z ojcostwa Boga, które nie jest ogólnikowe, nieokreślone i bez wpływu na historię, ale osobowe oraz ukierunkowane na miłość do każdego człowieka (por. Mt 6,25-30). Papież zwraca uwagę, że ludzkie braterstwo odrodziło się w Jezusie Chrystusie przez Jego śmierć i Zmartwychwstanie. Krzyż powinien być symbolem powstania braterstwa, którego człowiek nie jest w stanie sam stworzyć. Jezus Chrystus, który przyjął naturę ludzką, aby ją odkupić, przez swoje zmartwychwstanie stwarza nową ludzkość, w pełnej komunii $\mathrm{z}$ wolą Bożą i Jego planem obejmującym pełną realizację powołania do braterstwa ${ }^{20}$.

Franciszek podkreśla, że cenną pomocą w zrozumieniu istoty braterstwa jako podstawy dążenia do pokoju są encykliki jego poprzedników. Pierwszą z nich jest Populorum Progressio Pawła VI, która przedstawia integralny rozwój narodów jako nowe imię pokoju. Paweł VI podkreślał, że nie tylko ludzie, ale również państwa powinny dążyć do braterstwa, wzajemnej życzliwości i przyjaźni ${ }^{21}$. Drugą encykliką jest Sollicitudo rei socialis Jana Pawła II, w której pokój określony został jako opus solidaritatis (dzieło solidarności). Jan Paweł II podkreślał, że

pokój jest dobrem niepodzielnym - albo jest dobrem wszystkich, albo też nie jest dobrem niczyim. Może on być rzeczywiście osiągnięty i wykorzystywany jako najlepsza jakość życia i jako najbardziej ludzki i zrównoważony rozwój tylko wówczas, gdy we wszystkich obudzi się mocna i trwała wola angażowania się na rzecz dobra wspólnego ${ }^{22}$.

Chrześcijańska cnota solidarności zakłada, że bliźni powinien być miłowany nie tylko jako istota ludzka z jej prawami i podstawową równością wobec wszystkich, ale jako żywy obraz Boga, odkupiony krwią Chrystusa i poddany stałemu działaniu Ducha Świętego ${ }^{23}$.

Braterstwo w kontekście międzynarodowym spełnia istotną rolę, gdyż pomaga tłumić wojnę. Jest to szczególnie ważne w sytuacji, w której wiele współczesnych konfliktów rozgrywa się przy powszechnej obojętności. W życiu wielu narodów konflikty zbrojne uniemożliwiają

\footnotetext{
19 Ibidem.

20 Por. ibidem, s. 6.

21 Por. Paweł VI, Encyklika Populorum Progressio, O popieraniu rozwoju ludów, Watykan 26 marca 1967 r. http://www.opoka.org.pl/biblioteka/W/WP/pawel_vi/ encykliki/populorum_progressio_26031967.html, n.43.

$22 \quad$ Franciszek, Braterstwo podstawa..., op. cit., s. 6

23 Por. Jan Paweł II, Encyklika Sollicitudo rei socialis Ojca Świętego Jana Pawła II, Z okazji dwudziestej rocznicy ogtoszenia Populorum progressio, Rzym 30 grudnia 1987 r., [w:] Dzieła zebrane Jana Pawła II, t. I, Kraków 2006, n. 40.
} 
Teologia papieża Franciszka

osiągnięcie zgody międzynarodowej, powodując głębokie podziały i bolesne rany. Każda wojna jest rezygnacją z wysiłków na rzecz budowania ładu międzynarodowego, który powinien być najważniejszym celem dla wszystkich narodów ${ }^{24}$.

Braterstwo rodzi pokój, gdyż stwarza równowagę między wolnością a sprawiedliwością, między odpowiedzialnością osobistą a solidarnością, między dobrem indywidualnym a dobrem wspólnym. Stąd rodzi się papieskie przekonanie, że wspólnota polityczna w każdym kraju powinna dążyć do takiego braterstwa, które z jednej strony sprzeciwia się wszelkim przejawom egoizmu, niszczenia praworządności, sprawiedliwości i godności człowieka, zaś z drugiej strony pomaga w przejrzystym i odpowiedzialnym działaniu na rzecz dobra wspólnego danego narodu. Franciszek zwraca uwagę, że wymaga to jednak ciągłego odkrywania i miłowania braterstwa, które powinno być stale doświadczane, głoszone i okazywane, aby mogło być określane jako nowe imię pokoju ${ }^{25}$.

\section{Dialog jako główna droga do pokoju}

Kolejnym wskazaniem pastoralnym dla dyplomatów jest dążenie do dialogu. W trakcie spotkania z korpusem dyplomatycznym 12 stycznia 2014 roku Franciszek stwierdził, że: „Wszędzie drogą do rozwiązania otwartych problemów musi być dyplomatyczna droga dialogu"26. Jest to główna droga, która prowadzi do osiągnięcia oraz utrwalenia pokoju na świecie. W papieskiej ocenie rozpoczęcie dialogu w sytuacjach konfliktowych, wymaga wielkiej odwagi. Franciszek jako przykład podaje wznowienie rokowań pokojowych między Izraelczykami a Palestyńczykami, w celu odnalezienia sprawiedliwych i trwałych rozwiązań toczącego się od wielu lat konfliktu²7. Kolejnym przykładem było porozumienie zawarte między Stanami Zjednoczonymi i Kubą. Prowadzony dialog między tymi państwami przerwał milczenie trwające od ponad pół wieku i rozpoczął proces wzajemnego zbliżania się obydwu narodów ${ }^{28}$.

24 Por. Franciszek, Braterstwo podstawa..., op. cit., s. 8.

25 Por. ibidem.

Por. Franciszek, Główną droga..., op. cit., s. 17.

Por. ibidem.

28 Por.Franciszek, Przemówienie Papieża Franciszka do korpusu dyplomatycznego akredytowanego przy Stolicy Apostolskiej, Sala Królewska Pałacu Apostolskiego (12 stycznia 2015 r.) http://w2.vatican.va/content/francesco/pl/speeches/2015/ january/documents/papa-francesco_20150112_corpo-diplomatico.html. 
W trakcie spotkania z prezydentem i przedstawicielami władz państwowych w Ankarze 28 listopada 2014 roku Franciszek podkreślił, że:

Potrzebujemy dialogu, który pogłębiłby znajomość i rozważnie dowar-

tościował wiele rzeczy, które nas łączą, a jednocześnie pozwolił nam rozważyć różnice z mądrością i z pogodnym usposobieniem, abyśmy mogli również z nich wyciągnąć naukę ${ }^{29}$.

Dialog sprzyja poszanowaniu godności i podstawowych praw człowieka i narodu oraz prowadzi do budowy trwałego pokoju. W ten sposób pomaga przezwyciężyć uprzedzenia i obawy, stwarzając odpowiedni klimat dla wzajemnego szacunku, współpracy oraz rozwoju. Klimat ten oddala różnorodne nieporozumienia i prowadzi zwaśnione strony do pojednania.

Franciszek z niepokojem obserwuje sytuację na Bliskim Wschodzie, który od wielu lat jest sceną bratobójczych wojen. Wydarzenia w tej części świata domagają się konstruktywnego dialogu. Jednak, aby mógł on w pełni zaistnieć, należy wszystkim zagwarantować wolność religijną i wolności słowa, które rozwijają przyjaźni i relacje między różnorodnymi grupami społecznymi. Działanie to może doprowadzić do współpracy i stworzyć odpowiedni klimat do prowadzenia negocjacji na rzecz trwałego pokoju na Bliskim Wschodzie ${ }^{30}$.

\section{Zaangażowanie dyplomatów na rzecz budowy pokoju na świecie}

Ostatnim wskazaniem pastoralnym dla dyplomatów jest ich zaangażowanie na rzecz pokoju. W trakcie pierwszego spotkania z korpusem dyplomatycznym 22 marca 2013 roku Franciszek podkreślił, że należy podjąć bardziej zdecydowane działania w kwestii osiągania i utrwalania pokoju na świecie ${ }^{31}$. Największym zagrożeniem dla pokoju we współczesnym świecie, w dalszym ciągu pozostają toczące się konflikty zbrojne, gdyż ,pokazują najbardziej znamienne oblicze kultury odrzucenia, ponieważ ludzkie życie jest rozmyślnie znieważane przez tych, którzy mają władzę"32.

Idem, Wierzacy zjednoczeni przeciwko fanatyzmowi $i$ fundamentalizmowi, Spotkanie z prezydentem i przedstawicielami władz państwowych w Ankarze (28 listopada 2014 r.), L'OssRom (Pl) 12 (2014), s. 22.

30 Por. ibidem.

31 Por. Franciszek: Działajcie na rzecz..., op. cit., s. 25-27. 
Teologia papieża Franciszka
Przemawiając do korpusu dyplomatycznego 12 stycznia 2015 roku Papież stwierdził, że konsekwencją toczących się konfliktów na Bliskim Wschodzie jest odradzający się fundamentalizm religijny, który rozprzestrzenił się na państwa sąsiednie takie, jak: Syria oraz Irak. Fundamentalizm religijny odrzuca Boga i wykorzystuje Go tylko do walki ideologicznej. Jego ofiarami są przede wszystkim chrześcijanie oraz inne grupy etniczne i religijne m.in. jazydzi. W papieskiej ocenie potrzebna jest stanowcza i jednomyślna reakcja całej wspólnoty międzynarodowej, aby powstrzymać przemoc i terror oraz przywrócić zgodę. Pomóc w tym może podjęcie konkretnych inicjatyw i działań o charakterze dyplomatycznym na rzecz obrony tych, którzy są prześladowani oraz zmuszani do opuszczenia własnych domów i ojczyzny ${ }^{33}$. Dyplomaci powinni dążyć do tego, aby przywódcy religijni, polityczni, intelektualiści (zwłaszcza muzułmańscy), potępiali wszelkie przejawy fundamentalistycznych oraz ekstremistycznych interpretacji religii, które usprawiedliwiają przemoc i terror ${ }^{34}$.

Zdaniem Franciszka wiele wspólnot chrześcijańskich znajdujących się na Bliskim Wschodzie daje świadectwo wiary i męstwa w dążeniu do pojednania i rozwoju społeczeństw, w których żyją. Przykładem współistnienia różnorodnych wspólnot etnicznych i religijnych jest Republika Albanii. Przemawiając do przedstawicieli rządu i władz państwowych tego kraju Papież podkreślił, że „pokojowe i owocne współżycie ludzi i wspólnot należących do różnych religii nie tylko jest pożądane, ale również praktycznie możliwe i wykonalne" ${ }^{35}$. Pokojowe współżycie pojedynczych osób oraz grup społecznych jest bezcennym dobrem, które pomaga w rozwoju narodu i prowadzi do pokoju ${ }^{36}$.

Spotykając się z przedstawicielami rządu i władzami państwowymi w pałacu prezydenckim w Seulu 14 sierpnia 2014 roku Franciszek podkreślił, że: „Pokój nie jest po prostu brakiem wojny, lecz «dziełem sprawiedliwości». A sprawiedliwość jako cnota wymaga ćwiczenia się w cierpliwości" "37. Jest to droga, która prowadzi do przebaczenia, tolerancji, dialogu oraz wzajemnej współpracy. Wymaga ona jednak

$33 \quad$ Por. idem, Wierzacy zjednoczeni..., op. cit., s. 23.

34 Por. idem, $W$ poszukiwaniu trwałego pokoju, przemówienie podczas spotkania z władzami państwowymi w pałacu królewskim w Ammanie (24 maja 2014 r.), L'OssRom (PL) 6 (2014), s. 5.

Por. idem, Pokojowe wspótistnienie..., op. cit., s. 11.

Por. ibidem.

Por. Franciszek, W krainie spokojnego poranka, spotkanie z przedstawicielami rządu i władz państwowych w pałacu prezydenckim w Seulu (14 sierpnia 2014 r.), L'OssRom (PL) 8-9 (2014), s. 5 
dobrej woli obu stron, w rozpoznawaniu i osiąganiu celów prowadzących do pokoju ${ }^{38}$. Papież jest przekonany, że jednym z najważniejszych zadań dyplomacji powinno być stworzenie odpowiednich warunków pod budowę trwałego pokoju na świecie. Powinny być one oparte na fundamencie sprawiedliwości, respektowania godności, praw i bezpieczeństwa każdej ze stron. Dlatego dyplomacja powinna wystrzegać się działań, które nie służą osiągnięciu prawdziwego porozumienia. Tak kształtowany pokój, przyniesie liczne dobrodziejstwa dla danego narodu, regionu i całego świata ${ }^{39}$. Franciszek podkreśla, że aby

osiągnąć dobro, jakim jest pokój, trzeba przede wszystkim do niego wychowywać, odrzucając kulturę konfliktu, która dąży do zastraszenia drugiego, do zepchnięcia na margines tych, którzy myślą lub żyją inaczej ${ }^{40}$.

Konfliktów nie należy ignorować, lecz trzeba się z nimi zmierzyć.

Gdy zatrzymujemy się w sytuacji konfliktowej, tracimy poczucie głębokiej jedności rzeczywistości, powstrzymujemy historię i popadamy w wewnętrzne wyniszczanie przez bezowocne sprzeczności ${ }^{41}$.

\section{Podsumowanie}

Z powyższych treści wynika, że respektowanie godności człowieka, przezwyciężanie ubóstwa, braterstwo, dialog oraz zaangażowanie dyplomatów na rzecz budowy pokoju na świecie, to najważniejsze wskazania pastoralne dla dyplomatów. Papieskie nauczanie kierowane jest do współczesnego dyplomaty, który ma wpływ na obecny i przyszły kształt świata, w którym żyjemy. Franciszek wzywa dyplomację do podjęcia działań w oparciu o wartości, które nie ulegają przelotnym modom. $\mathrm{Z}$ analizy papieskiego nauczania wynika, że w działaniach dyplomatycznych można dostrzec pewien paradoks. Z jednej strony dąży do sprawiedliwości i pokoju, zaś drugiej strony odrzuca argumenty aksjologiczne, na których można taki świat zbudować. Drogą prowadzącą do stworzenia pokojowego ładu międzynarodowego jest uporządkowanie relacji w wymiarze transcendentnym oraz międzyludzkim.

38 Por. ibidem.

$39 \quad$ Por. Franciszek, Pora zdobyć się na odwage w stużbie dobra, przemówienie podczas spotkania z władzami palestyńskimi w Betlejem (25 maja 2014 r.), L'OssRom (PL) 6 (2014), s. 9.

$40 \quad$ Idem, Pamięć, odwaga, utopia, przemówienie w Radzie Europy (25 listopada 2014 r.), L'OssRom (PL) 12 (2014), s. 14. 
Teologia papieża Franciszka

Niezbędne w tej kwestii jest prowadzenie konstruktywnego dialogu. Sprzyja on rokowaniom, które są kluczem do rozwiązania wielu problemów zagrażających światowemu pokoju.

Franciszek wyraźnie zachowuje równowagę między poprawnością nauczania a poprawnością postępowania. Jego nauczanie do dyplomatów jest praktyczne i poruszające istotę problemów, z którymi dyplomaci powinni się zmierzyć. Papież proponuje drogę braterstwa jako płaszczyznę łączącą różne narody w dążeniu do ładu międzynarodowego. $Z$ nauczania Franciszka do dyplomatów wynika także nowe spojrzenie na rolę dyplomacji we współczesnym świecie. Powinna ona budować mosty łączące wszystkich ludzi i narody, w taki sposób, aby każdy mógł znaleźć w drugim człowieku i narodzie swojego brata, a nie wroga czy konkurenta. Dlatego wzywa dyplomatów, aby dawali odważne i radosne świadectwo wiary i braterskiej miłości, których uczy Jezus Chrystus.

Słowa kluczowe: dyplomacja, wartości moralne, Franciszek, moralność dyplomacji.

\section{Bibliografia:}

1. Franciszek, Braterstwo podstawa pokoju i droga do niego, Orędzie na Światowy Dzień Pokoju (1 stycznia 2014 r.), „L'Osservatore Romano” wydanie polskie 1(2014), s. 4-10.

2. Franciszek, Budowanie pokoju wymaga poszanowania wolności i godności wszystkich, przemówienie podczas wizyty u prezydenta Izraela (26 maja 2014 r.), „L'Osservatore Romano” wydanie polskie 6 (2014), s. 23-24.

3. Franciszek, Dziatajcie na rzecz budowana pokoju, audiencja dla korpusu dyplomatycznego akredytowanego przy Stolicy Apostolskiej (22 marca 2013 r.), „L'Osservatore Romano” wydanie polskie 5 (2013), s. 25-27.

4. Franciszek - papież niewygodny? http://www.niedziela.pl/artykul/6887/ Franciszek---papiez-niewygodny (23.11.2013).

5. Franciszek, Gtówna droga pokoju jest dialog, audiencja dla korpusu dyplomatycznego (12 stycznia 2014 r.), „L'Osservatore Romano” wydanie polskie 2 (2014), s. 15-19.

6. Franciszek, Nie można akceptować prześladowań z powodu wiary, przemówienie do uczestników kongresu poświęconego wolności religijnej i prawu międzynarodowemu (20 czerwca 2014 r.), „L'Osservatore Romano” wydanie polskie 7 (2014), s. 13-14.

7. Franciszek, Między godnościa i transcendencja, przemówienie w Parlamencie Europejskim (25 listopada 2014 r.), „LOsservatore Romano” 12 (2014), s. 9-13.

8. Franciszek, Pamięć, odwaga, utopia, przemówienie w Radzie Europy (25 listopada 2014 r.), „L'Osservatore Romano” wydanie polskie 12 (2014), s. 14-18. 
9. Franciszek, Pieniądz musi stużyć, a nie rządzić, audiencja dla nowych ambasadorów przy Stolicy Apostolskiej (16 maja 2013 r.), „L'Osservatore Romano" wydanie polskie 7 (2013), s. 13-14.

Teologia papieża Franciszka

10. Franciszek, Pokojowe wspótistnienie różnych religii jest możliwe, spotkanie z przedstawicielami rządu i władz państwowych w pałacu prezydenckim w Tiranie ( 21 września 2014 r.), „L'Osservatore Romano” wydanie polskie 10 (2014), s. 10-11.

11. Franciszek, Pora zdobyć się na odwage w stużbie dobra, przemówienie podczas spotkania z władzami palestyńskimi w Betlejem (25 maja 2014 r.), „L'Osservatore Romano” wydanie polskie 6 (2014), s. 9-10.

12. Franciszek, Przemówienie Papieża Franciszka do korpusu dyplomatycznego akredytowanego przy Stolicy Apostolskiej, Sala Królewska Pałacu Apostolskiego (12 stycznia 2015 r.) http:/w2.vatican.va/content/francesco/ pl/speeches/2015/january/documents/papa-francesco_20150112_corpodiplomatico.html.

13. Franciszek, Wierzacy zjednoczeni przeciwko fanatyzmowi i fundamentalizmowi, spotkanie z prezydentem i przedstawicielami władz państwowych w Ankarze (28 listopada 2014 r.), „L'Osservatore Romano” wydanie polskie 12 (2014), s. 22-23.

14. Franciszek, W krainie spokojnego poranka, spotkanie z przedstawicielami rządu i władz państwowych w pałacu prezydenckim w Seulu (14 sierpnia 2014 r.), „L'Osservatore Romano” wydanie polskie 8-9 (2014), s. 4-5.

15. Franciszek, W poszukiwaniu trwałego pokoju, przemówienie podczas spotkania z władzami państwowymi w pałacu królewskim w Ammanie (24 maja 2014 r.), „L'Osservatore Romano” wydanie polskie 6 (2014), s. 5.

16. Jan Paweł II, Encyklika Sollicitudo rei socialis Ojca Świętego Jana Pawta II, Z okazji dwudziestej rocznicy ogłoszenia Populorum progressio, Rzym 30 grudnia 1987 r., [w:] Dzieła zebrane Jana Pawta II, t. I, Kraków 2006, s. 280-324.

17. Paweł VI, Encyklika Populorum Progressio, O popieraniu rozwoju ludów, Watykan 26 marca 1967 r. http://www.opoka.org.pl/biblioteka/W/WP/pawel_vi/encykliki/populorum_progressio_26031967.html. 